\title{
The Risk Assessment of Multi Hazard Area: A Case of Mitigation Consider in Spatial Planning of Bukittinggi City
}

\author{
Firmansyah, Deden Syarifudin and Jajan Rohjan \\ Urban dan Regional Planning Studies Program, Faculty of Engineering, Universitas Pasundan, Jalan Setiabudhi \\ No. 193, Bandung, West Java, Indonesia, 40153.
}

Received: 2018-04-14 Accepted: 2019-11-19

Keywords:

risk assessment; multihazard; mitigation; spatial planning

Correspondent Email: firmansyah@unpas.ac.id

\begin{abstract}
The city of Bukittinggi in West Sumatra Province is geographically prone to multi hazard. The located along the active fault line of Sumatra namely Ngarai Sianok that shifted eleven centimeters per year, which is surrounded by two volcanoes, namely Mount Singgalang and Mount Marapi. Looking at the potential of multihazard disasters, this study aims to analyze the multi-disaster that is the input for development policy. The method used to assess factors with Davidson standardization model and superimpose. To obtain the level of importance of disaster risk factors used weighting by using analytical hierarchy process method by expert judgement. The study results show areas at high risk for earthquake, landslide, fire and flood disasters and disaster mitigation measures to reduce risks to hazard, vulnerability and resilience factors. Contribution in this reseach that spatial multi-hazard consideration should be undertaken as a consideration of development policies in order to reduce disaster risk.
\end{abstract}

(c) 2019 by the authors. This article is an open access article distributed under the terms and conditions of the Creative Commons Attribution(CC BY NC) licensehttps://creativecommons.org/licenses/by-nc/4.0

\section{Introduction}

The region of Sumatra Island is located in the subduction area which is a meeting of two active/ tectonic crust plates, namely Eurasian Plate and IndoAustralian Plate. On March 6th, 2007, the earthquake struck Solok, Tanah Datar, and Bukittinggi. The earthquake incident caused the deaths of 8 people died and caused huge losses of property and infrastructure damage in Bukittinggi City. Damage to structures at the time of occurrence is difficult to predict and different from the reality but the approach needs to be done at the time of the occurrence of danger (Jaimes, Reinoso, \& Esteva, 2015), in addition to assessing the damage to buildings that impact on the rebuilding costs to be considered (Fuchs, Keiler, \& Zischg, 2015; van Verseveld, van Dongeren, Plant, Jäger, \& den Heijer, 2015).

The earthquake that occurred on March 6, 2007, also triggered a landslide, which occurred in the Ngarai Sianok border, causing several houses around it to fall into the Valley of the Ngarai Sianok. The biggest impact is the area of Belakang Balok and Birugo Village (District of Aur Birugo Tigo Baleh), Bukit Cangang Ramang and Kayu Kubu Village (District of Guguak Panjang) and several houses on collapsed in Bukik Bulek at Village of Campago Guguak Bulek (Regional Disaster Management Agency of Bukittinggi City, 2014). On the other hand the cause of the fire that occurred in the city of Bukittinggi more triggered by the earthquake, human error factor and weather factors. Earthquakes that occur sometimes often cause electrical shorting and eventually cause a fire. In the year 2012, there are fires in District Aur Birgo Baleh is 9 incidents, District Guguk Panjang as much as 27 incidents and District Mandiangin Koto Selayan as many as 21 events (Regional Disaster Management Agency of Bukittinggi City, 2014).

Seeing the potential of disaster owned by the City of Bukittinggi, making it as issue issues that must be considered in the development planning side of Bukittinggi City. Resilience to disaster should be prepared in policy to combat destructive impacts that can happen at any time (Ayyub, 2014), (Borg, Indirli, Romagnoli, Rochas, \& Kuzn,ecova, 2014) then utilizing internet technology and early warning system in preventive (Collins \& Kapucu, 2008). And take advantage of international technology There is also a disaster that comes with the warning but there is also a sudden arrival, so that required more systematic disaster management jointly both by the government and by the community. An urgent matter in the study is to give consideration to policy makers that adaptation to multi-hazard hazards, site considerations, impacted areas and spatial dangers should be made. Spatial temporal assessment needs to be done so that it can be a tool to improve preparedness in the mitigation of disaster and early warning system in preventive (Fuchs et al., 2015). 
On the other hand, the urban planning of Bukittinggi City (RTRW) 2010-2030 that has been prepared, has not been able to adapt multi-hazard disaster in the implementation of its spatial planning policies. This cannot be ignored, because the fundamentals of hazards caused by disasters must be important considerations in determining city plans, preparing programs to anticipate hazards, making mitigation policies, developing post-disaster programs and recovery and strengthening infrastructure to support disaster mitigation. Therefore, adjustments to urban planning in Bukittinggi City are needed, especially when reviewing every 5 years the implementation of city plans.

In relation thereto, a review of multi-hazard disaster risk assessment and mitigation guidance is needed in Bukittinggi City. Referrals and challenges in multi-hazard analysis need to be presented for policy considerations (Melanie S. Kappes, Keiler, von Elverfeldt, \& Glade, 2012). Thus, its contribution is urgent to provide operational guidance for development in areas considered to be disaster-prone areas, which in turn will create a sense of security, comfortable for residents of Bukittinggi City to live and move.

The danger of nature is a condition of natural phenomena, in which nature makes changes to achieve its equilibrium. Natural hazards do not always cause natural disasters but natural disasters occur if natural hazards are in areas susceptible to these natural hazards. Whereas according to the Act Number 24 Year 2007 on disaster management gives the definition of disaster is an event or series of events that threaten and disrupt the lives and livelihoods of people caused by both natural and/or non-natural factors and human factors resulting in the occurrence of human fatalities, Environmental damage, property loss, and psychological impact.

The region of Sumatra Island, Indonesia is located in the subduction area which is a meeting of two active/tectonic earth plate, the Eurasian Plate and Indo-Australian Plate. Earthquake disasters also cause collateral hazard, namely: the danger of landslides and fires. For the city of Bukittinggi, landslide disaster is also potential due to the hilly topography factor. This research is based on the potential danger of disasters in Bukittinggi City as input in the planning of Bukittinggi City area.

It is understood that natural hazard and disaster as part of environmental or natural events in any condition. The types of disasters earthquakes, floods, volcanoes and violent weather variations by giving the limitation that the disaster is extreme beyond human will (Awotona,1997). Here we can understand the uncertainty of the event, pose a danger to the human side. Although natural events contain uncertainty, humans can actually conduct an assessment of the physical geography through vulnerability. Several studies have shown the importance of preventive action in disaster by assessing the potential for disaster in the form of multi hazard assessment map in urban areas (Bathrellos, Skilodimou, Chousianitis, Youssef, \& Pradhan, 2017), on the active vulcano area (Thierry, Stieltjes, Kouokam, Nguéya, \& Salley, 2008), hazard hurricane (van Verseveld et al., 2015), land slide (van Westen, van Asch, \& Soeters, 2006). This multi-hazard concern suggests how important it is to respond to hazards in urban areas because it poses a risk to the survival that we need to save on the other hand the government understands the actions taken.

An important follow-up action of the disaster analysis is post-disaster mitigation. Understanding to Berke \& Campanella (2006) mitigation measures are to reduce damage and casualties ("The term "mitigation" has a long history in the field of emergency management, where it refers predisaster actions to reduce damage and injury from natural hazard, a definition that includes both adaptation and mitigation measures", P. 218). Mitigation refers to pre-disaster action to reduce damage and injury from natural hazards (Sanderson,1997). Disaster can be viewed as a result of hazard-induced disaster, vulnerability due to hazard and durability, ability to overcome or in other words capacity.

From some of these meanings, it can be concluded that a disaster is an event that occurs because of the encounter of external threats to human life with vulnerability. Other factors related to disaster are capacities, which are positive aspects of the existing situation, which if mobilized can reduce risk by reducing vulnerability. Reducing the risk of natural hazard can be described as reducing vulnerability and increasing capacity. On the other hand, the most important to know that is about the vulnerability (vulnerability) and endurance as one factor that affects the natural disaster. Hazard factor is a basic physical factor that is the trigger of disaster. Many researchers have discussed the hazards but few have exposed the hazard in the field of research in multi-hazard (Melanie Simone Kappes, 2011). Therefore in this study multihazard must be limited to hazards and vulnerability because it is very determining the method used.

The earthquake an understanding as follows an earthquake is an earthly vibration that occurs as a result of the sudden release of energy accumulated in the deformed rock (Perry \& Lindell, 2008). Earthquakes can be defined as wave propagation in the rock/soil period derived from the release of kinetic energy coming from within the earth. The source of energy released can come from the collision of plates, volcanic eruptions, or landslide periods of rock/soil (Lin Moe \& Pathranarakul, 2006). From this understanding, it can be concluded that earthquakes are natural phenomena that can happen at any time on the surface of the earth. Earthquakes cause shocks or vibrations of varying magnitude. The magnitude of earth shocks ranges from 
very small to the tremendous shock, the shocks cause damage and collapse of building structures that cause casualties to its inhabitants.

The explanation of landslide understanding is landslide/erosion is the process of sweeping the soil by the urgings or forces of water and wind, whether naturally occurring or as a result of human activities (Carter, 2008). In relation to natural erosion and human acceleration, the causes and factors that influence the rate of erosion are soil climate (Jayasuriya \& McCawley, 2010), topography (Purwandari, Hadi, \& Kingma, 2011), ground cover (vegetation) and the type of human activity (Sakijege, 2013). It's mean the erosion process consists of three consecutive stages peeling (detachment), transportation and sedimentation. An important soil release agent is a drop of raindrops falling to the ground. The droplets will hit the ground, causing the clods of soil to become smaller and dislodged grains.

The definition of fire is the existence of an unwanted fire. Fire events begin with burning then the fire is out of control and threatens the safety of life and property(Carter, 2008; Jayasuriya \& McCawley, 2010).

Flooding is defined as the flooding of a place due to the overflow of water that exceeds the capacity of water disposal in a region and causes physical, social and economic losses (Ayyub, 2014). Flooding is a seasonal threat that occurs when water bodies overflow from existing channels and inundate surrounding areas. Flooding is the most common and most harmful natural threat, both humanitarian and economic (Komendantova et al., 2014).

The level of vulnerability is an important factor to be recognized as one of the factors affecting the occurrence of 'natural disasters (Melanie Simone Kappes, 2011), as new disasters will occur when 'natural hazards' occur in 'vulnerable conditions' (Melanie S. Kappes et al., 2012). According to vulnerability definition is a characteristic of people or groups in terms of their capacity to anticipate and survive the impact of hazards. "... .vulnerability as the characteristics of a person or group in terms of their capacity to anticipate, cope with, resist, and recover from the impact of natural hazard (Awotona,1997).

The above theory explains that vulnerability as a "characteristic of a person or group in terms of their resilience/ability to anticipate, cope, reject, recover from the effects of natural hazards. Resilience factors are the ability to respond or overcome the impact of a natural disaster. Simply representing a positive aspect of an existing situation or an emergency response. In other words, resilience is a positive aspect of the existing situation to reduce the risk of natural hazards (Bathrellos et al., 2017),based on modification resilience is divided into 2 sub factors, namely resources and mobility.

Mitigation is all efforts and activities undertaken to reduce or minimize the threat of disaster, especially if prevention activities can not be implemented, while keep-sign is all efforts and activities of introduction to the source of ben. Menurut Campanella dan Godschalk (2012) ("The term "mitigation" has a long history in the field of emergency management, where it refers predisaster actions to reduce damage and injury from natural hazard, a definition that includes both adaptation and mitigation measures," P. 118). On the other hand, that understanding mitigation refers to the action before the disaster to reduce damage and injury victims from natural hazards.

\section{The Methods}

Research conducted using a mixed method approach. Where to determine the level of danger and vulnerability using based on perception through expert judgment or analytical hierarchy process which is a qualitative approach. Meanwhile, to determine the spatial area for each earthquake risk, landslide, fire, and flood based on the dimensions of hazard, vulnerability, and capacity factor, qualitative is used. The approach used in this research is qualitative based on the superimposed method on the analytical tool used by GIS using Arc-view version 3.3 software.

The research area was carried out in Bukittinggi on the map coordinates $110^{\circ} 20^{\prime}-100^{\circ} 25^{\prime}$ ' Longitude and $00^{\circ} 16^{\prime}-00^{\circ} 20^{\prime}$ Latitude with an altitude of 780 to $950 \mathrm{~m}$ above sea level. The total area of $25,239 \mathrm{~km}^{2}$ is comparable to $0.06 \%$ of the area of West Sumatra Province which administratively consists of 3 Districts and 24 Villages (See Figure 1).

The method of the approach taken in this research through several phasing as follows:

- $\quad$ Review the literature in formulating the factors used to assess the risk level of earthquake, landslide/land movement, fire and flood in terms of three dimensions such as hazard, vulnerability, and capacity factor (see Table 1). Data collected includes maps, documents, studies, population and social data from disaster and spatial related agencies such as the National Disaster Management Agency of Bukittinggi, Public Works Agency, Regional Development Planning Agency, Sanitary, Parks and Fire, Society Agency of Bukittinggi.

- Determination of weighting of each factor, sub factors and indicators through expert judgment of 40 respondents who understand disaster information working at the National Disaster Management Agency of Bukittinggi (10 respondens), Public Works Agency (10 respondens), Regional Development Planning Agency (10 respondens), Sanitary, Parks and Fire, Society Agency of Bukittinggi (10 respondens) calculated using Analitycal Hierarchy Process (AHP).

- $\quad$ Calculating risk index and formulating risk level of earthquake, landslide, fire and flood for each kelurahan in all areas of Bukittinggi City. 


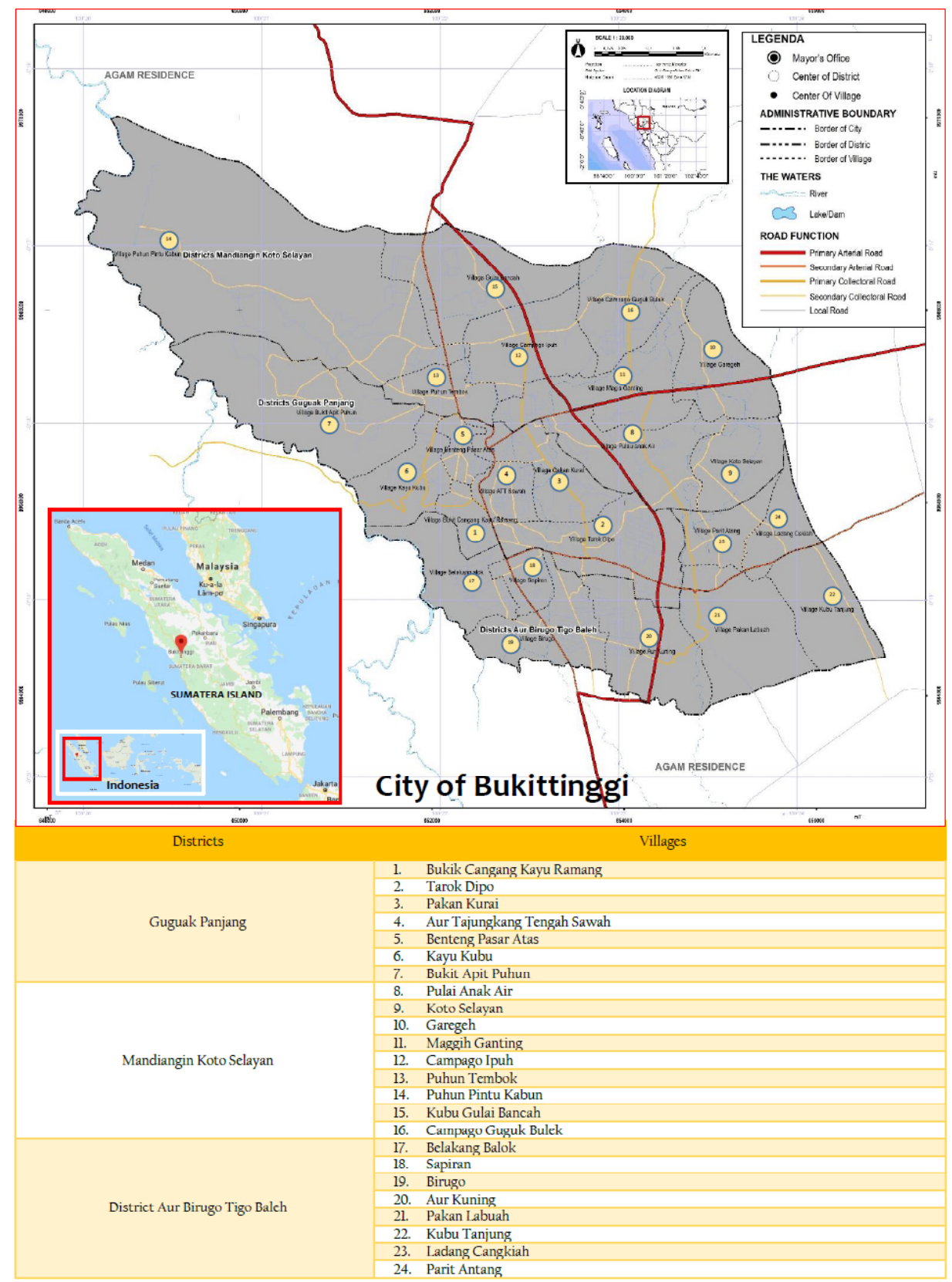

Figure 1. The area study of Bukittinggi City

- The process of mapping the results of disaster calculations using overlay techniques using GIS. First of all the superimpose analysis process with GIS is done to determine the level of earthquake hazard, landslide, fire and flood into 3 categories of low, medium and high. The map preparation used are; [1] the spatial structure map and the land use of the city plan (RTRW year 2010-2033) based on the Bukittinggi Regional Development Planning Agency (Bappeda Kota Bukittinggi)1:50,000 map scales; [2] earthquake disaster maps such landslide, fire and flood (based from National Disaster Management Agency of the Republic of Indonesia 2017) map scale 1: 50,000; [3] Topographic map, soil type, geology, hydrology based on
Bukittinggi Regional Development Planning Agency (Bappeda Kota Bukittinggi) 1: 50,000 map scales. After obtaining a map of the results of overlay hazard on earthquake hazard, landslide, fire, and flood results from the determination of the risk index based on AHP on the dimensions of hazard, vulnerability, and capacity factor, a multi-hazard analysis is produced, especially on the pattern of residential space and land use with high activity by the community.

- To formulate appropriate mitigation directives for the development of Bukittinggi City area, to reduce losses caused by earthquake, landslide, fire and flood based on the analysis of the risk level of the natural disaster. 
Table 1. Factors, Sub Factors and Indicators of Disaster Risk Based on Type of Disaster

\begin{tabular}{|c|c|c|c|c|c|}
\hline \multirow{2}{*}{ Factors } & \multirow{2}{*}{$\begin{array}{r}\text { Sub- } \\
\text { factors }\end{array}$} & \multicolumn{4}{|c|}{ Indicators (type of disaster) } \\
\hline & & Earthquakes & Landslide & Fire & Flooding \\
\hline Hazard & $\begin{array}{l}\mathrm{P} \quad \mathrm{r} \text { o } \mathrm{n} \text { e } \\
\text { Disaster }\end{array}$ & $\begin{array}{l}\text { - High } \\
\text { earthquake } \\
\text { hazards } \\
\text { - Medium } \\
\text { earthquake } \\
\text { hazards } \\
\text { - Low earthquake } \\
\text { hazards }\end{array}$ & $\begin{array}{l}\text { - High landslide } \\
\text { hazards } \\
\text { - Medium } \\
\text { landslide } \\
\text { hazards } \\
\text { - Low landslide } \\
\text { hazards }\end{array}$ & $\begin{array}{l}\text { - High fire } \\
\text { hazards } \\
\text { - Medium fire } \\
\text { hazards } \\
\text { - Low fire } \\
\text { hazards }\end{array}$ & $\begin{array}{l}\text { - High flood } \\
\text { hazards } \\
\text { - Medium flood } \\
\text { hazards } \\
\text { - Low flood } \\
\text { hazards }\end{array}$ \\
\hline Vulnerability & $\begin{array}{l}\text { Physical } \\
\text { Vulnerability }\end{array}$ & - Building density & $\begin{array}{l}\text { - Rainfall } \\
\text { - Building } \\
\text { density } \\
\text { - Land capability }\end{array}$ & $\begin{array}{l}\text { - Building } \\
\text { density } \\
\text { - Physical } \\
\text { condition of } \\
\text { building }\end{array}$ & $\begin{array}{l}\text { - Rainfall } \\
\text { - Puddle area } \\
\text { - Number of } \\
\text { inundation } \\
\text { points }\end{array}$ \\
\hline & $\begin{array}{l}\text { S o c i a } 1 \text {, } \\
\text { Citizen } \\
\text { Vulnerability }\end{array}$ & $\begin{array}{l}\text { - Population } \\
\text { density } \\
\text { - Percentage } \\
\text { of female } \\
\text { population } \\
\text { - Percentage old } \\
\text { and under fives }\end{array}$ & $\begin{array}{l}\text { - Population } \\
\text { Density } \\
\text { - Percentage } \\
\text { of female } \\
\text { population } \\
\text { - Percentage old } \\
\text { and under fives }\end{array}$ & $\begin{array}{l}\text { - Population } \\
\text { Density } \\
\text { - Percentage } \\
\text { of female } \\
\text { population } \\
\text { - Percentage old } \\
\text { and under fives }\end{array}$ & $\begin{array}{l}\text { - Population } \\
\text { Density } \\
\text { - Percentage } \\
\text { of female } \\
\text { population } \\
\text { - Percentage old } \\
\text { and under fives }\end{array}$ \\
\hline & $\begin{array}{l}\text { Economics } \\
\text { Vulnerability }\end{array}$ & $\begin{array}{l}\text { Economic } \\
\text { activity center }\end{array}$ & $\begin{array}{l}\text { Economic } \\
\text { activity center }\end{array}$ & $\begin{array}{l}\text { Economic } \\
\text { activity center }\end{array}$ & $\begin{array}{l}\text { - Economic } \\
\text { activity center }\end{array}$ \\
\hline Capacity & $\begin{array}{l}\text { Artificial } \\
\text { Resource }\end{array}$ & $\begin{array}{l}\text { - Field ratio/ } \\
\text { Population } \\
\text { - Open space } \\
\text { ratio/Population } \\
\text { - Evacuation } \\
\text { place ratio/ } \\
\text { Population } \\
\text { - Ratio of health } \\
\text { facilities/ } \\
\text { Population } \\
\text { - Doctor ratio/ } \\
\text { Population }\end{array}$ & $\begin{array}{l}\text { - Field ratio: } \\
\text { Population } \\
\text { - Open } \\
\text { space ratio/ } \\
\text { Population } \\
\text { - Evacuation } \\
\text { place ratio/ } \\
\text { Population } \\
\text { - Ratio of health } \\
\text { facilities/ } \\
\text { Population } \\
\text { - Doctor ratio/ } \\
\text { Population }\end{array}$ & $\begin{array}{l}\text { - Field ratio: } \\
\text { Population } \\
\text { - Open } \\
\text { space ratio/ } \\
\text { Population } \\
\text { - Evacuation } \\
\text { place ratio/ } \\
\text { Population } \\
\text { - Ratio of health } \\
\text { facilities/ } \\
\text { Population } \\
\text { - Doctor ratio/ } \\
\text { Population } \\
\text { - Number of } \\
\text { hydrant }\end{array}$ & $\begin{array}{l}\text { - Field ratio: } \\
\text { Population } \\
\text { - Open space } \\
\text { ratio/Population } \\
\text { - Evacuation } \\
\text { place ratio/ } \\
\text { Population } \\
\text { - Ratio of health } \\
\text { facilities/ } \\
\text { Population } \\
\text { - Doctor ratio/ } \\
\text { Population }\end{array}$ \\
\hline & Mobility & & & - Accessibility & \\
\hline
\end{tabular}

Source: Analysis Result, 2016.

The formula used to calculate the value of each disaster risk factor is:

$$
\begin{aligned}
& \mathrm{B}=\mathrm{WB} 1 \mathrm{X}^{\prime} \mathrm{B} 1+\ldots \ldots \ldots . .+\mathrm{WBnX} \mathrm{X}^{\prime} \mathrm{Bn} \\
& \mathrm{R}=\mathrm{WR} 1 \mathrm{X}^{\prime} \mathrm{R} 1+\ldots \ldots \ldots . .+\mathrm{WRnX} X^{\prime} \mathrm{Rn} \\
& \mathrm{K}=\mathrm{WK} 1 \mathrm{X}^{\prime} \mathrm{K} 1+\ldots \ldots \ldots \ldots .+\mathrm{WKnX} K \mathrm{Kn}
\end{aligned}
$$

Where (B) is the value of hazard factors, $(\mathrm{R})$ is a value of vulnerability factor, $(\mathrm{K})$ is the value of resilience/ capacity, $\left(\mathrm{X}^{\prime} \mathrm{i}\right)$ is a value of any indicator that has been standardized, (Wi) is the weight of each indicator.
To calculate the level of disaster risk is done by calculating the level of vulnerability and endurance level using statistics and with the help of Geographic Information System (GIS) (Purwandari et al., 2011; Sakijege, 2013), the risk of natural disaster in Bukittinggi City is calculated based on disaster type in Bukittinggi City covering landslide, earthquake and Fire disaster as in Table 1. 


\section{Result and Discussion}

\section{Earthquake disaster risk level}

Regionally that City of Bukittinggi is in Tufa Batuapung spread which is also called as Tufa Maninjau and Andesite Gunung Marapi unity of spread. Surface of geology describes the physical properties of rock and soil weathering. The outcrop of Tapa Batuapung is found as the canyon of Sianok canyon, this rock is white to light brown. In dry state is quite compact and somewhat dense, so as to form a nearly vertical cliff tens of meters tall. Seeing the geological condition as potential as disaster-prone zones. Earthquake hazard zone is generally divided into three zone areas, such low vulnerability zone, medium vulnerability zone and high vulnerability zone. The division of this prone zone is based on:

- Low prone zones are usually based on relatively compact tertiary-aged rocks but potentially avalanche in the event of an earthquake.

- Medium prone zone, usually based on tuff, sand, clay and silt deposits of relatively compact volcanic material deposition.

- High prone zone, usually based on alluvium deposits, wet swamps and river basins with potential liquefaction in the event of an earthquake.
The results of the earthquake hazard calculation are identified through several variables, namely the area of the high disaster prone zone, and the area of medium disaster prone zone. Based on the results of the identification of the extent of the earthquake disaster zone, the value of high disaster-prone zones and the area of medium disaster prone zones. For the calculation of the value of earthquake risk levels are calculated based on the average value, it can be classified earthquake levels from 0.49 to 5.96 is Low, 5.97 to 11.44 is Medium, 11,45-16,92 is High as presented in Table 2. The earthquake risk level in Bukittinggi City which has a high level of disaster risk is located in Bukik Apit Puhun Village. As for the area of Pulai Anak Air, Maggih Ganting, Campago Ipuh, Puhun Pintu Kabun, Kubu Gulai Bancah, and Behind the average beam (See Figure 2).

The vulnerability can be defined as the characteristics and situations of a person or group covering physical, environmental, social, and economic factors that increase the likelihood of suffering the impact of a hazard. The vulnerability can also be interpreted as a factor determining how much impact is felt in case besides, there is also a capacity factor, namely the control of resources, attitudes, and capabilities possessed by the community, enabling them to maintain and prepare themselves to prevent, cope, and recover from the impact of disasters.

Tabel 2. Analysis of Earthquake Disaster Risk Level

\begin{tabular}{|c|c|c|c|c|c|c|c|c|}
\hline \multirow[b]{2}{*}{ Village/Location } & \multicolumn{2}{|c|}{ Hazard } & \multicolumn{2}{|c|}{ Vulnerability } & \multicolumn{2}{|c|}{ Endurance } & \multirow[b]{2}{*}{$\begin{array}{l}\text { Risk } \\
\text { index }\end{array}$} & \multirow[b]{2}{*}{$\begin{array}{c}\text { Level of } \\
\text { risk }\end{array}$} \\
\hline & index & $\begin{array}{c}\text { Value } \mathrm{x} \\
\text { Weight } \\
\text { hazard } \\
(0,50)\end{array}$ & Index & $\begin{array}{c}\text { Value } \mathrm{x} \\
\text { Weight } \\
\text { vulnerability } \\
(0,25)\end{array}$ & index & $\begin{array}{c}\text { Value } \mathrm{x} \\
\text { Weight } \\
\text { endurance } \\
(0,25)\end{array}$ & & \\
\hline \multicolumn{9}{|l|}{ District Guguak Panjang } \\
\hline $\begin{array}{l}\text { Bukik Cangang Kayu } \\
\text { Ramang }\end{array}$ & 0.77 & 0.39 & 1.8 & 0.45 & 4.4 & 1.10 & 1.94 & Low \\
\hline Tarok Dipo & 1.83 & 0.92 & 3.16 & 0.79 & 4.4 & 1.10 & 2.81 & Low \\
\hline Pakan Kurai & 1.34 & 0.67 & 1.93 & 0.48 & 4.4 & 1.10 & 2.25 & Low \\
\hline $\begin{array}{l}\text { Aur Tajungkang Tengah } \\
\text { Sawah }\end{array}$ & 0.93 & 0.47 & 2.84 & 0.71 & 4.4 & 1.10 & 2.28 & Low \\
\hline Benteng Pasar Atas & 0.56 & 0.28 & 2.6 & 0.65 & 4.4 & 1.10 & 2.03 & Low \\
\hline Kayu Kubu & 2.26 & 1.13 & 1.09 & 0.27 & 4.4 & 1.10 & 2.50 & Low \\
\hline Bukit Apit Puhun & 6.83 & 3.42 & 1.15 & 0.29 & 4.4 & 1.10 & 4.80 & Moderate \\
\hline $\begin{array}{l}\text { District Mandiangin } \\
\text { Koto Selayan }\end{array}$ & & 0.00 & & & & & & \\
\hline Pulai Anak Air & 2.4 & 1.20 & 1.59 & 0.40 & 4.53 & 1.13 & 2.73 & Low \\
\hline Koto Selayan & 1.14 & 0.57 & 0.68 & 0.17 & 4.53 & 1.13 & 1.87 & Low \\
\hline Garegeh & 1.4 & 0.70 & 1.58 & 0.40 & 4.53 & 1.13 & 2.23 & Low \\
\hline Maggih Ganting & 2.21 & 1.11 & 2.25 & 0.56 & 4.53 & 1.13 & 2.80 & Low \\
\hline Campago Ipuh & 2.19 & 1.10 & 1.93 & 0.48 & 4.53 & 1.13 & 2.71 & Low \\
\hline Puhun Tembok & 1.24 & 0.62 & 3.14 & 0.79 & 4.53 & 1.13 & 2.54 & Low \\
\hline Puhun Pintu Kabun & 16.91 & 8.46 & 1.25 & 0.31 & 4.53 & 1.13 & 9.90 & High \\
\hline
\end{tabular}




\begin{tabular}{|c|c|c|c|c|c|c|c|c|}
\hline \multirow[b]{2}{*}{ Village/Location } & \multicolumn{2}{|c|}{ Hazard } & \multicolumn{2}{|c|}{ Vulnerability } & \multicolumn{2}{|c|}{ Endurance } & \multirow[b]{2}{*}{$\begin{array}{l}\text { Risk } \\
\text { index }\end{array}$} & \multirow[b]{2}{*}{$\begin{array}{l}\text { Level of } \\
\text { risk }\end{array}$} \\
\hline & index & $\begin{array}{c}\text { Value } \mathrm{x} \\
\text { Weight } \\
\text { hazard } \\
(0,50)\end{array}$ & Index & $\begin{array}{c}\text { Value } \mathrm{x} \\
\text { Weight } \\
\text { vulnerability } \\
(0,25)\end{array}$ & index & $\begin{array}{c}\text { Value } x \\
\text { Weight } \\
\text { endurance } \\
(0,25)\end{array}$ & & \\
\hline Kubu Gulai Bancah & 3.77 & 1.89 & 1.61 & 0.40 & 4.53 & 1.13 & 3.42 & Low \\
\hline Campago Guguk Bulek & 2.75 & 1.38 & 1.76 & 0.44 & 4.53 & 1.13 & 2.95 & Low \\
\hline \multicolumn{9}{|l|}{$\begin{array}{l}\text { District Aur Birugo Tigo } \\
\text { Baleh }\end{array}$} \\
\hline Belakang Balok & 2.49 & 1.25 & 1.81 & 0.45 & 4.45 & 1.11 & 2.81 & Low \\
\hline Sapiran & 0.49 & 0.25 & 1.59 & 0.40 & 4.45 & 1.11 & 1.76 & Low \\
\hline Birugo & 1.83 & 0.92 & 1.3 & 0.33 & 4.45 & 1.11 & 2.35 & Low \\
\hline Aur Kuning & 1.34 & 0.67 & 2.94 & 0.74 & 4.45 & 1.11 & 2.52 & Low \\
\hline Pakan Labuah & 1.58 & 0.79 & 1.3 & 0.33 & 4.45 & 1.11 & 2.23 & Low \\
\hline Kubu Tanjung & 1.17 & 0.59 & 1.05 & 0.26 & 4.45 & 1.11 & 1.96 & Low \\
\hline Ladang Cangkiah & 0.79 & 0.40 & 1.24 & 0.31 & 4.45 & 1.11 & 1.82 & Low \\
\hline Parit Antang & 0.74 & 0.37 & 1.33 & 0.33 & 4.45 & 1.1125 & 1.82 & Low \\
\hline
\end{tabular}

Source : Analysis Result, 2016

\section{Landslide risk level}

The area that has a landslide potential is in the Ngarai Sianok Cliff area. At the top of the cliff is often found a very wide burly, especially when there is water flow into it. Based on the data of free development laboratory (swelling) this rock exceeds $70 \%$. This figure is one of the factors that indicate the easy disruption of the stability of the slope/cliff if infiltrate by water. In the case of no exposure or disturbance, this rock has a considerable carrying capacity of more than 3.75 $\mathrm{kg} / \mathrm{cm}^{2}$ of weathering material in the form of clay, silt and loam clay, less pass water with a smaller order of $10-6 \mathrm{~cm} / \mathrm{s}$. Water that flows on this soil will flow more on the surface. Further below 2 meters depth, usually a fine to coarse tuff, very obsolete with a graduation order ranging from $10-3$ to $10-4 \mathrm{~cm} / \mathrm{s}$. Based on the data sonder generally concluded that the foundation of the foundation of the building can be placed on the tufa layer which is generally below the depth of 4 meters. In the area located in Andesite Units of Mount Marapi (Qama), the physical properties of silt lempau with medium dents (10-4 to $10-6 \mathrm{~cm} / \mathrm{s})$, easily eroded, thickness between 2.5 meter to 5 meters.

The calculation of factor values with Davidson standardization is used for the analysis of statistical data based on administrative boundaries (nonphysical), such as for social and economic vulnerability subdivisions, resource and mobility resilience subfactors. For the analysis results with this method, it's assumed that the results of the analysis by the analysis unit village will be the same at every level (for example: if village $(\mathrm{X})$ has a degree of economic vulnerability is high, then the whole region village $(\mathrm{X})$ shall be deemed to mean that have a level of economic vulnerability high).
Standardization of indicator value is intended to produce standard value, so that can be done mathematical calculation with other indicator with standardization model which is used for the indicator whose value correspond with disaster risk.

From the analysis that the high landslide level is in Village Kayu Kubu, Bukit Apit Puhun, Pulai Anak Air, Maggih Ganting, Campago Ipuh, Kubu Gulai Bancah, Campago Guguk Bulek and Belakang Batok for more details can be seen in Table 3 and Figure 3.

The landslide that occurred on the Ngarai Sianok Coast so swept away some houses around it fell into the valley of the Ngarai Sianok. The degree of vulnerability of soil movement can be divided into four levels: (1) Very low, rare earth movement occurs. (2) Low, ground motion can occur when there is interference. (3) Medium, soil movement potentially occurs when rainfall is high and there is a disruption to the slope. (4) High, frequent soil movement during the rainy season and long active movement of the land back.

Building density is also an assessment in the determination of landslide vulnerability in Bukittinggi City. The density of buildings within a region also affects the vulnerability of earthquake disasters, where the density of buildings can worsen the fall of losses, such as victims and material. The high building density allows the area to have the high vulnerability. From the risk assessment using the building density and slope of the slope within the high vulnerability zone greater than $30 \%$. Calculation of landslide vulnerability can be identified through several variables, namely population density, building density, and land capacity. 
Table 3. Landslide risk landscape analysis

\begin{tabular}{|c|c|c|c|c|c|c|c|c|}
\hline \multirow[b]{2}{*}{ Village/Location } & \multicolumn{2}{|c|}{ Hazard } & \multicolumn{2}{|c|}{ Vulnerability } & \multicolumn{2}{|c|}{ Endurance } & \multirow[b]{2}{*}{$\begin{array}{l}\text { Risk } \\
\text { index }\end{array}$} & \multirow[b]{2}{*}{$\begin{array}{l}\text { Level of } \\
\text { risk }\end{array}$} \\
\hline & index & $\begin{array}{c}\text { Value } \mathrm{x} \\
\text { Weight } \\
\text { hazard } \\
(0,50)\end{array}$ & Index & $\begin{array}{c}\text { Value } \mathrm{x} \\
\text { Weight } \\
\text { vulnerability } \\
(0,25)\end{array}$ & index & $\begin{array}{c}\text { Value } \mathrm{x} \\
\text { Weight } \\
\text { endurance } \\
(0,25) \\
\end{array}$ & & \\
\hline \multicolumn{9}{|l|}{ District Guguak Panjang } \\
\hline $\begin{array}{l}\text { Bukik Cangang Kayu } \\
\text { Ramang }\end{array}$ & 0.21 & 0.11 & 2.13 & 0.53 & 5.2 & 1.30 & 1.94 & Low \\
\hline Tarok Dipo & 0.1 & 0.05 & 1.71 & 0.43 & 5.2 & 1.30 & 1.78 & Low \\
\hline Pakan Kurai & 0.14 & 0.07 & 1.57 & 0.39 & 5.2 & 1.30 & 1.76 & Low \\
\hline $\begin{array}{l}\text { Aur Tajungkang Tengah } \\
\text { Sawah }\end{array}$ & 0.12 & 0.06 & 1.64 & 0.41 & 5.2 & 1.30 & 1.77 & Low \\
\hline Benteng Pasar Atas & 0.43 & 0.22 & 2.32 & 0.58 & 5.2 & 1.30 & 2.10 & Low \\
\hline Kayu Kubu & 0.47 & 0.24 & 2.73 & 0.68 & 5.2 & 1.30 & 2.22 & Low \\
\hline Bukit Apit Puhun & 1.37 & 0.69 & 2.88 & 0.72 & 5.2 & 1.30 & 2.71 & Moderate \\
\hline \multicolumn{9}{|l|}{$\begin{array}{l}\text { District Mandiangin Koto } \\
\text { Selayan }\end{array}$} \\
\hline Pulai Anak Air & 0.6 & 0.30 & 1.61 & 0.40 & 5.33 & 1.33 & 2.04 & Low \\
\hline Koto Selayan & 0.06 & 0.03 & 1.12 & 0.28 & 5.33 & 1.33 & 1.64 & Low \\
\hline Garegeh & 0.14 & 0.07 & 1.69 & 0.42 & 5.33 & 1.33 & 1.83 & Low \\
\hline Maggih Ganting & 0.71 & 0.36 & 2.18 & 0.55 & 5.33 & 1.33 & 2.23 & Low \\
\hline Campago Ipuh & 0.47 & 0.24 & 2.15 & 0.54 & 5.33 & 1.33 & 2.11 & Low \\
\hline Puhun Tembok & 0.25 & 0.13 & 2.06 & 0.52 & 5.33 & 1.33 & 1.97 & Low \\
\hline Puhun Pintu Kabun & 3.95 & 1.98 & 3.46 & 0.87 & 5.33 & 1.33 & 4.17 & High \\
\hline Kubu Gulai Bancah & 1.08 & 0.54 & 2.03 & 0.51 & 5.33 & 1.33 & 2.38 & Low \\
\hline Campago Guguk Bulek & 0.8 & 0.40 & 2.05 & 0.51 & 5.33 & 1.33 & 2.25 & Low \\
\hline \multicolumn{9}{|l|}{$\begin{array}{l}\text { District Aur Birugo Tigo } \\
\text { Baleh }\end{array}$} \\
\hline Belakang Balok & 0.47 & 0.24 & 2.92 & 0.73 & 5.25 & 1.31 & 2.28 & Low \\
\hline Sapiran & 0.03 & 0.02 & 2.34 & 0.59 & 5.25 & 1.31 & 1.91 & Low \\
\hline Birugo & 0.41 & 0.21 & 2.12 & 0.53 & 5.25 & 1.31 & 2.05 & Low \\
\hline Aur Kuning & 0.03 & 0.02 & 2.24 & 0.56 & 5.25 & 1.31 & 1.89 & Low \\
\hline Pakan Labuah & 0.03 & 0.02 & 1.42 & 0.36 & 5.25 & 1.31 & 1.68 & Low \\
\hline Kubu Tanjung & 0.03 & 0.02 & 1.25 & 0.31 & 5.25 & 1.31 & 1.64 & Low \\
\hline Ladang Cangkiah & 0.03 & 0.02 & 1.13 & 0.28 & 5.25 & 1.31 & 1.61 & Low \\
\hline Parit Antang & 0.06 & 0.03 & 1.07 & 0.27 & 5.25 & 1.31 & 1.61 & Low \\
\hline
\end{tabular}

\section{Fire Risk Level}

Fire is the secondary impact of the earthquake, a fire occurred shortly after the earthquake at Wahyu toys shop, Kamang Jaya Restaurant, Gon Jaya Restaurant, Bukittingi City Market Management Office and Bukittinggi Tour Market which burned more than 200 stalls. Fires also occur in residential areas. Causes of fire that occurred in the city of Bukittinggi more triggered by the earthquake, human error factor and weather factors. Earthquakes occasionally often cause electric concepts and ultimately lead to fires. In 2012 there are fires in District Aur Birgo Baleh as many as 9 events, District Guguk Panjang as many as 27 events and District Mandiangin Koto Selayan as many as 21 events. Estimated losses suffered by the fire is about
IDR 8,235,257,000. In 2013 the number of fire incident as many as 13 events, in Sub Mandianin Koto Selayan as many as 13 events, and the most fire incident in District Guguk Panjang as many as 14 events.

Guguak Panjang District is more potential or high risk due to high density. Density becomes the main factor of high susceptibility in a region because the more dense a region it will facilitate the fire to propagate because of the dense building structure and coincide between one building with another building. The average population density of Bukittinggi City in 2011 was 4,500 people $/ \mathrm{km}^{2}$, up compared to 2010 which was only 4,410 people $/ \mathrm{km}^{2}$. However, this density is uneven across the district. Guguk Panjang sub-district is the densest subdistrict, which is 6,186 people $/ \mathrm{km}^{2}$ 
followed by Aur Birugo Tigo Baleh 4,039 people/ $\mathrm{km}^{2}$ and Mandiangin Koto Selayan 3,789 people $/ \mathrm{km}^{2}$.

For the calculation of the fire disaster vulnerability value value is calculated based on the average value it can be classified 0.77-1.52 low vulnerability rate, 1.532,281 moderate susceptibility level, and 2.29-3.04 high vulnerability level. For more details can be seen in Table 4 and Figure 4 . The capacity of fire disasters is distinguished by the availability of water resources in emergency response of fire disasters. This analysis uses the availability of reservoirs in the Village in tackling the fire disaster.

Building density is also an assessment in determining fire vulnerability in Bukittinggi City. The density of buildings in a region also affects the vulnerability of fire disasters, where the density of buildings can worsen the fall of losses, such as victims and material (Carter, 2008). The high building density allows the area to have high vulnerability, this requires a way of understanding the social community build a network of volunteers in understanding and providing knowledge to the community in various opportunities to overcome the danger (Benton, 2016). In addition to the density of buildings vulnerability to fire disasters is a building made or dominated by building materials made of wood. Dominasi material rumah yang digunakan oleh masyarakat harus menjadi bagian penting selain dominasi density perumahan (Ghermandi, Beletzky, de Torres Curth, \& Oddi, 2016). Material selection for high density areas should be recommended in reducing risk, as part of fire disaster management (Wong \& Xie, 2014). In Bukittinggi City there are still many buildings made of wood so it is very vulnerable to fire disaster. Fire vulnerability calculations can be identified through several variables: building density numbers, and buildings made of wood.

The other variables used to reduce the impact are vacant land, field, Green Open Space emergency. Response in mitigation such as direct assistance that can be received by citizens such as Indonesian Military help or volunteers. From the result of risk fire disaster risk analysis in Bukittinggi City which has the highest level of disaster risk is in Bukit Cangang Kayu Ramang Village. Ramang, Tarok Dipo, Benteng Pasar Atas, dan Kayu Kubu.

Table 4. fire disaster risk level analysis

\begin{tabular}{|c|c|c|c|c|c|c|c|c|}
\hline \multirow[b]{2}{*}{ Village/Location } & \multicolumn{2}{|c|}{ Hazard } & \multicolumn{2}{|c|}{ Vulnerability } & \multicolumn{2}{|c|}{ Endurance } & \multirow[b]{2}{*}{$\begin{array}{l}\text { Risk } \\
\text { index }\end{array}$} & \multirow[b]{2}{*}{$\begin{array}{c}\text { Level of } \\
\text { risk }\end{array}$} \\
\hline & index & $\begin{array}{c}\text { Value } \mathrm{x} \\
\text { Weight } \\
\text { hazard } \\
(0.50)\end{array}$ & Index & $\begin{array}{c}\text { Value } \mathrm{x} \\
\text { Weight } \\
\text { vulnerability } \\
(0.25)\end{array}$ & index & $\begin{array}{c}\text { Value } \mathrm{x} \\
\text { Weight } \\
\text { endurance } \\
(0.25)\end{array}$ & & \\
\hline \multicolumn{9}{|l|}{ District Guguak Panjang } \\
\hline $\begin{array}{l}\text { Bukik Cangang Kayu } \\
\text { Ramang }\end{array}$ & 13.46 & 6.73 & 0.77 & 0.19 & 6.28 & 1.57 & 8.49 & High \\
\hline Tarok Dipo & 13.46 & 6.73 & 2.9 & 0.73 & 6.28 & 1.57 & 9.02 & High \\
\hline Pakan Kurai & 13.46 & 6.73 & 2.94 & 0.74 & 6.28 & 1.57 & 9.03 & High \\
\hline $\begin{array}{l}\text { Aur Tajungkang Tengah } \\
\text { Sawah }\end{array}$ & 13.46 & 6.73 & 2.76 & 0.69 & 6.28 & 1.57 & 8.99 & High \\
\hline Benteng Pasar Atas & 13.46 & 6.73 & 2.81 & 0.70 & 6.28 & 1.57 & 9.00 & High \\
\hline Kayu Kubu & 13.46 & 6.73 & 2.47 & 0.62 & 6.28 & 1.57 & 8.92 & High \\
\hline $\begin{array}{l}\text { Bukit Apit Puhun } \\
\text { District Mandiangin Koto }\end{array}$ & 0 & 0 & 1.69 & 0.42 & 6.28 & 1.57 & 1.99 & Low \\
\hline \multicolumn{9}{|l|}{ Selayan } \\
\hline Koto Selayan & 0 & 0 & 0.84 & 0.21 & 5.94 & $\begin{array}{l}1.40 \\
1.48\end{array}$ & 1.69 & Low \\
\hline Garegeh & 0 & 0 & 1.11 & 0.28 & 5.94 & 1.48 & 1.76 & Low \\
\hline Maggih Ganting & 13.46 & 6.73 & 2.95 & 0.74 & 5.94 & 1.48 & 8.95 & High \\
\hline Campago Ipuh & 13.46 & 6.73 & 1.56 & 0.39 & 5.94 & 1.48 & 8.60 & High \\
\hline Puhun Tembok & 13.46 & 6.73 & 2.53 & 0.63 & 5.94 & 1.48 & 8.85 & High \\
\hline Puhun Pintu Kabun & 0 & 0 & 1.51 & 0.38 & 5.94 & 1.48 & 1.86 & Low \\
\hline Kubu Gulai Bancah & 0 & 0 & 1.68 & 0.42 & 5.94 & 1.48 & 1.90 & Low \\
\hline $\begin{array}{l}\text { Campago Guguk Bulek } \\
\text { District Aur Birugo Tigo }\end{array}$ & 0 & 0 & 1.13 & 0.28 & 5.94 & 1.48 & 1.77 & Low \\
\hline \multicolumn{9}{|c|}{ Baleh } \\
\hline Sapiran & 13.46 & 6.73 & 3.02 & 0.76 & 5.24 & 1.31 & 8.79 & High \\
\hline Birugo & 13.46 & 6.73 & 2.82 & 0.71 & 5.24 & 1.31 & 8.74 & High \\
\hline Aur Kuning & 13.46 & 6.73 & 2.31 & 0.58 & 5.24 & 1.31 & 8.62 & High \\
\hline Pakan Labuah & 0 & 0 & 1.59 & 0.40 & 5.24 & 1.31 & 1.71 & Low \\
\hline Kubu Tanjung & 0 & 0 & 1.46 & 0.37 & 5.24 & 1.31 & 1.67 & Low \\
\hline Ladang Cangkiah & 0 & 0 & 0.93 & 0.23 & 5.24 & 1.31 & 1.54 & Low \\
\hline Parit Antang & 0 & 0 & 0.81 & 0.20 & 5.24 & 1.31 & 1.51 & Low \\
\hline
\end{tabular}

Source : Analysis Result, 2016 


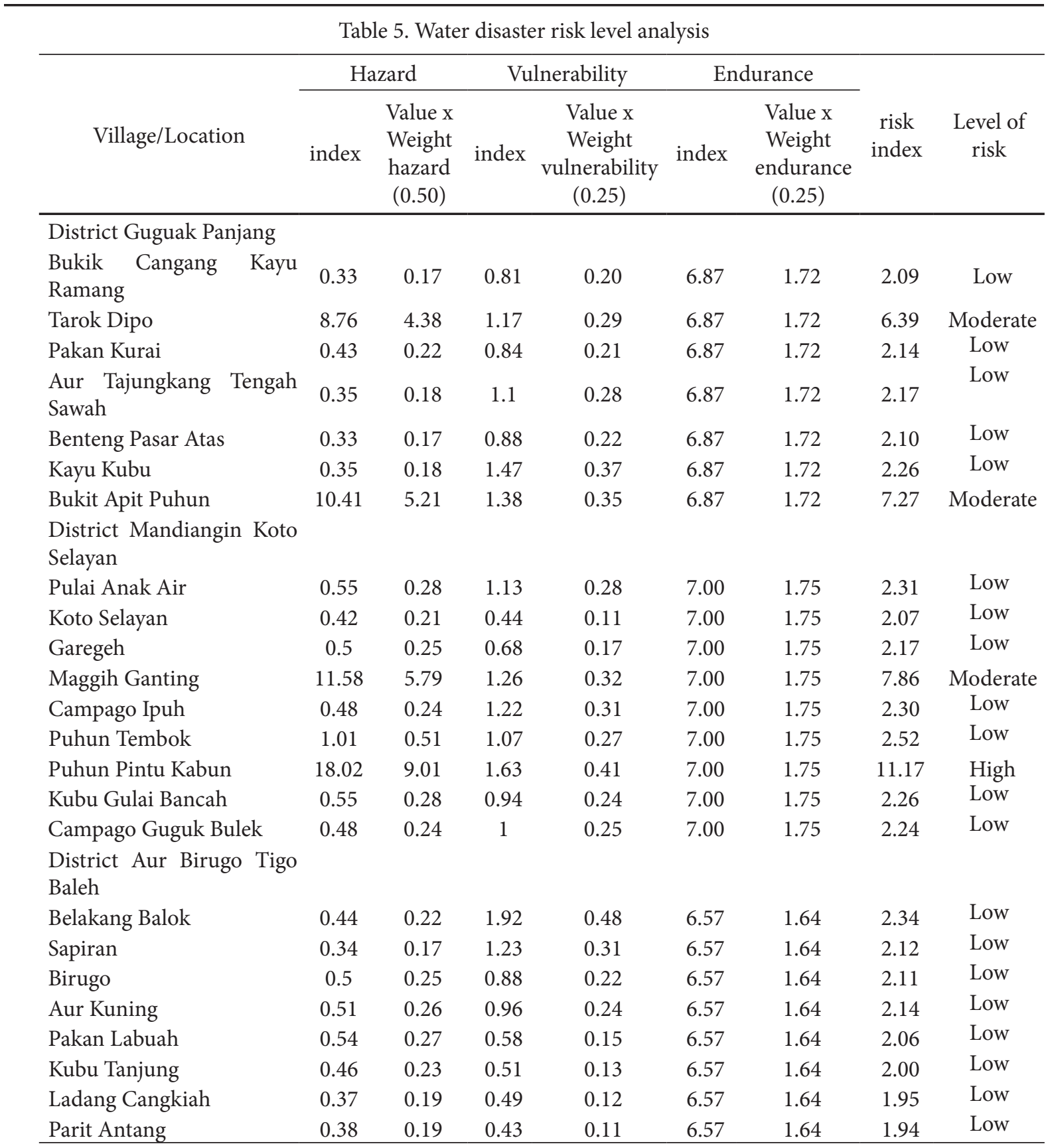

Source : Analysis Result, 2016

\section{Flood risk level}

The direction of the drainage flow depends on the slope of the land and the shape of the existing catchment area. Bukittinggi city is generally located at an altitude of 780 - 950 meter above sea level. Surrounded by hills to the North -West, and mountains to the south. Under these conditions, Bukittinggi City becomes a crossing of the regional watershed, which flows from upstream in the South and downstream in the Northeast. Likewise, the drainage system of Bukittinggi City supported by the regional river will drain the runoff of rainwater and other wastewater in gravity downstream in the Northeast and directly adjacent to Agam Regency. Upstream is the District of Banuhampu and downstream is District IV Angkat and District Tilatang Kamang. According to Master Plan Urban Drainage of Bukittinggi City can be divided into 6 drainage zone in accordance with the existing catchment area along with its tributaries. That is:

- Batang Agam catchment area, the total catchment area of 732.02 hectare with river length of 6,442 meters. Covering of district: Birugo Bagian Barat, Kayu Kubu, Benteng Pasar Atas, Aur Tanjungkang Tangah Sawah, Pakan Kurai, Bukit Apit Puhun, Tembok a Hal Puhun Pintu Kabun, Gulai Bancah, some Campago Ipuh villages. 
- Batang Tamburo catchment area, total catchment area 610,72 hectare with river length 5,534 meters. Covering district: a part of Aur Kuning, Pakan Labuh, Kubu Tanjung, Parit Antang, Ladang Cakiah, Koto Salayan, Garegeh, Pulai Anak Air, Manggis Ganting, Sebagian Guguk Bulek villages.

- Banda Catchment Area of Malang, wide of catchment area 268,76 hectare with River length 3,865 meters. Covering district: Some Pulai Anak Air, Manggis Ganting, Campago Ipuh, Guguk Bulek, Pakan Kurai villages.

- Catch of Banda Nagari Birugo, $98.51 \mathrm{Ha}$ of catchment area with the length of river 3,938 meters. Covering district: some of District Birugo, Sapiran, Aur Tajungkang Tangah Sawah, Tarok Dipo, Pakan Kurai villages.

- Banda Batu Ampa catchment area, a total area of catchment 109,71 hectare with the length of river 2,941 meters. Covering district: some Birugo, Aur Kuning, Tarok Dipo villages.

- Batang Sianok catchment area, 732.02 ha of catchment area with 5.950-meter long river length. Covering district: some Birugo, Bukit Cangang, Kayu Ramang, Kayu Kubu, Bukit Apit, Puhun Pintu Kabun villages.

For the calculation of flood disaster risk level value is calculated based on the average value it can be classified 0.85-1.85 low vulnerability level, 1.862,86 moderate susceptibility level, and 2.87-3,87 High vulnerability level (See Figure 5 ). Table 5 shows that kelurahans that have high risk of standing water are in Pulai Anak Air, Sapiran, Campago Guguk Bulek, Maggih Ganting, Bukit Apit Puhun villages.

The disaster management cycle needs to be done in full (Wong \& Xie, 2014). Resillience cycle prevention efforts on the emergence of impact is the main treatment in reducing the impact. In order to prevent flooding it is necessary to encourage community efforts and response in making better social networks that ultimately create preventive measures such as making absorption wells, and vice versa preventing deforestation of disasters should be done in full (Hemingway \& Gunawan, 2018). The other hand, to avoid waste leakage, it is necessary to prepare safety procedure and control on compliance of treatment. This behavioral compliance is influenced by various drivers and pull factors, including policies that support and integrate with other direct sector policies (Lin, 2018). Although prevention has been done, while the chances of an event still exist, mitigation efforts need to be made (Röthlisberger, Zischg, \& Keiler, 2017), such efforts to minimize the impact of disasters. There are two forms of mitigation, namely structural mitigation in the form of making infrastructure of impact minimization minimization, and nonstructural mitigation in the form of regulation, spatial management and training.

\section{Disaster risk/Multihazard}

From the analysis of flood disaster risk level in Bukittinggi city which has the highest disaster risk level is in Kelurahan Bukit Cangang K. Ramang, Tarok Dipo, Benteng Pasar Atas, Garegeh villages. As presented in Table 6 and Figure 6, a multi hazards cluster can be created as follows:

- Earthquakes, consists of a cluster Bukit Apit Puhun, cluster of Puhun Pintu Kabun, can be recommended in such spatial policy should be established with a vibration-resistant construction/earthquake, especially in areas prone to earthquakes, retrofitting buildings to follow the standards of quality of the building, retrofitting building existing vital structures, Plan settlement placement to reduce occupancy density in earthquake prone areas.

- Landslide consist of clusters Bukit Apit Puhun, Cluster of Puhun Pintu Kabun can be recommended as reshaping the steep slope (formation of land into more gentle slopes) in areas of potential landslides; Reinforcement of a steep slope with a bridge of wire on the foot of the slope; Planting of landslide vegetation; Closure cracks/fissures ground immediately because of the rainy season cracks can be filled by rain water into the soil so that the soil above impermeable layer; The wooden house building (semi-permanent) is more resistant to cracks than to the building of stone/brick pairs on the still moving land.

- $\quad$ Flooding consists of a cluster of locations Tarok Dipo, Cluster of Apit Puhun, Cluster of Maggih Genting, Cluster of Puhun Pintu Kabun can be recommended to create embankments adequate and create a reservoir of water to reduce the flood peak to add sewers to channel diversion or normalization river or floodway, drainage maintenance.

- Fire disaster consists of a cluster of locations Bukik Cangang Kayu Ramang, Cluster of Tarok Dipo, Cluster of Pakan Kurai, Cluster of Aur Tajungkang Tengah Sawah, Cluster of Benteng Pasar Atas, Cluster of Bukit Apit Puhun, Cluster of Maggih Ganting, Cluster of Puhun Tembok, Cluster of Belakang Balok, Cluster of Sapiran, Cluster of Birugo, Cluster of Aur Kuning can be recommended such as: Hydrant and reservoir making; Portable hydrants; Creation of rapid fire responsive access points. 
Table 6. Disaster risk analysis

\begin{tabular}{|c|c|c|c|c|c|}
\hline Village/Location & $\begin{array}{c}\text { Earthquake } \\
\text { disaster risk } \\
\text { level } \\
\end{array}$ & $\begin{array}{l}\text { Landslide risk } \\
\text { level }\end{array}$ & Fire risk level & Flood risk level & Multi hazard \\
\hline \multicolumn{6}{|l|}{ District Guguak Panjang } \\
\hline $\begin{array}{l}\text { Bukik Cangang Kayu } \\
\text { Ramang }\end{array}$ & Low & Low & High & Low & Fire \\
\hline Tarok Dipo & Low & Low & High & Moderate & Fire \\
\hline Pakan Kurai & Low & Low & High & Low & Fire \\
\hline $\begin{array}{l}\text { Aur Tajungkang Tengah } \\
\text { Sawah }\end{array}$ & Low & Low & High & Low & Fire \\
\hline Benteng Pasar Atas & Low & Low & High & Low & Fire \\
\hline Kayu Kubu & Low & Low & High & Low & Fire \\
\hline Bukit Apit Puhun & Moderate & Moderate & Low & Moderate & $\begin{array}{c}\text { Earthquake, } \\
\text { Landslide, and } \\
\text { Flood }\end{array}$ \\
\hline \multicolumn{6}{|l|}{$\begin{array}{l}\text { District Mandiangin } \\
\text { Koto Selayan }\end{array}$} \\
\hline Pulai Anak Air & Low & Low & Low & Low & Fire \\
\hline Koto Selayan & Low & Low & Low & Low & Fire \\
\hline Garegeh & Low & Low & Low & Low & Fire \\
\hline Maggih Ganting & Low & Low & High & Moderate & Fire,Flood \\
\hline Campago Ipuh & Low & Low & High & Low & Fire \\
\hline Puhun Tembok & Low & Low & High & Low & Fire \\
\hline Puhun Pintu Kabun & High & High & Low & High & $\begin{array}{c}\text { Earthquake, } \\
\text { Landslide, and } \\
\text { Flood }\end{array}$ \\
\hline Kubu Gulai Bancah & Low & Low & Low & Low & Fire \\
\hline Campago Guguk Bulek & Low & Low & Low & Low & Fire \\
\hline \multicolumn{6}{|l|}{$\begin{array}{l}\text { District Aur Birugo Tigo } \\
\text { Baleh }\end{array}$} \\
\hline Belakang Balok & Low & Low & High & Low & Fire \\
\hline Sapiran & Low & Low & High & Low & Fire \\
\hline Birugo & Low & Low & High & Low & Fire \\
\hline Aur Kuning & Low & Low & High & Low & Fire \\
\hline Pakan Labuah & Low & Low & Low & Low & Fire \\
\hline Kubu Tanjung & Low & Low & Low & Low & Fire \\
\hline Ladang Cangkiah & Low & Low & Low & Low & Fire \\
\hline Parit Antang & Low & Low & Low & Low & Fire \\
\hline
\end{tabular}

Source : Analysis Result, 2016 


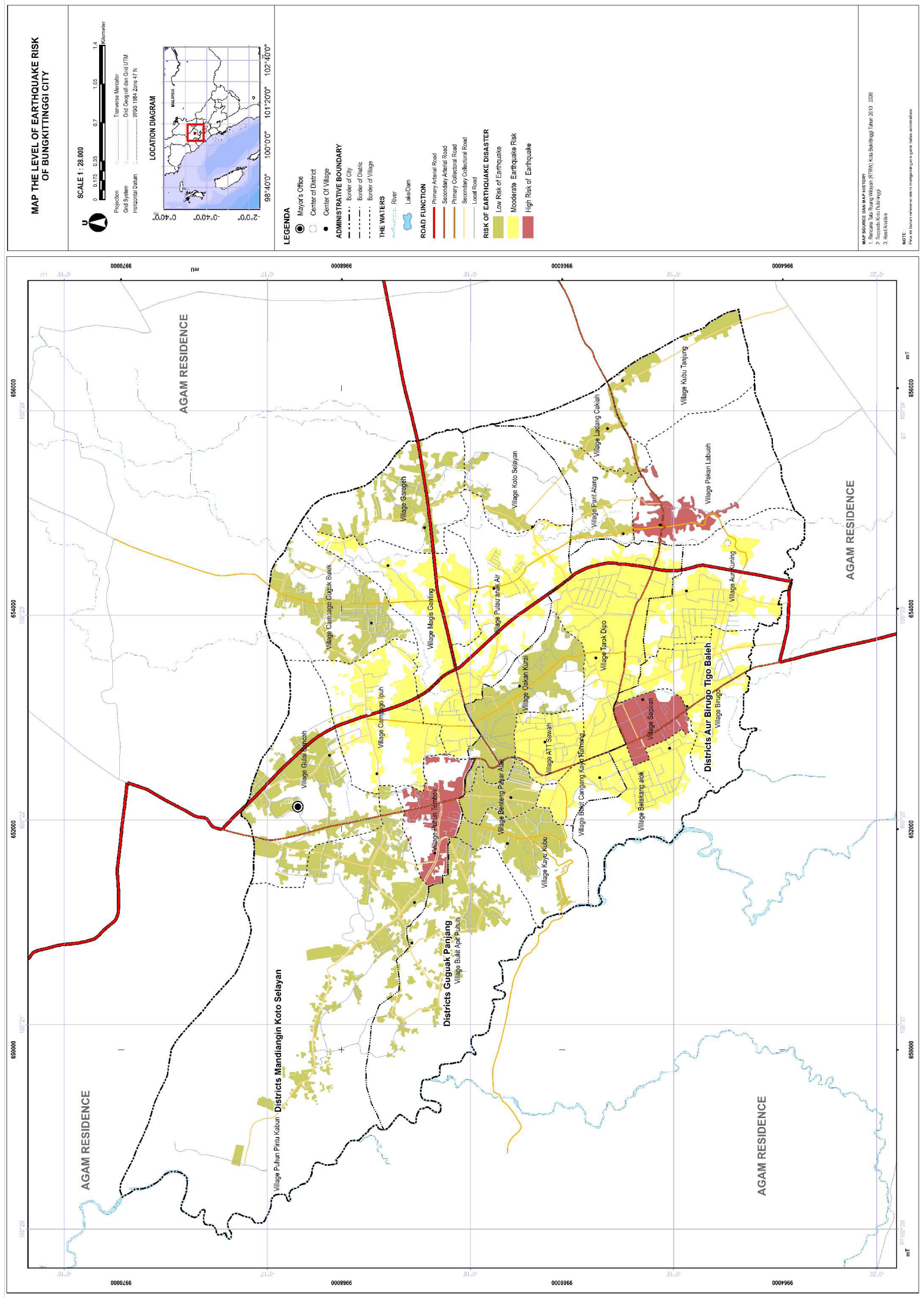

Figure 2. Spatial risk level of earthquake 


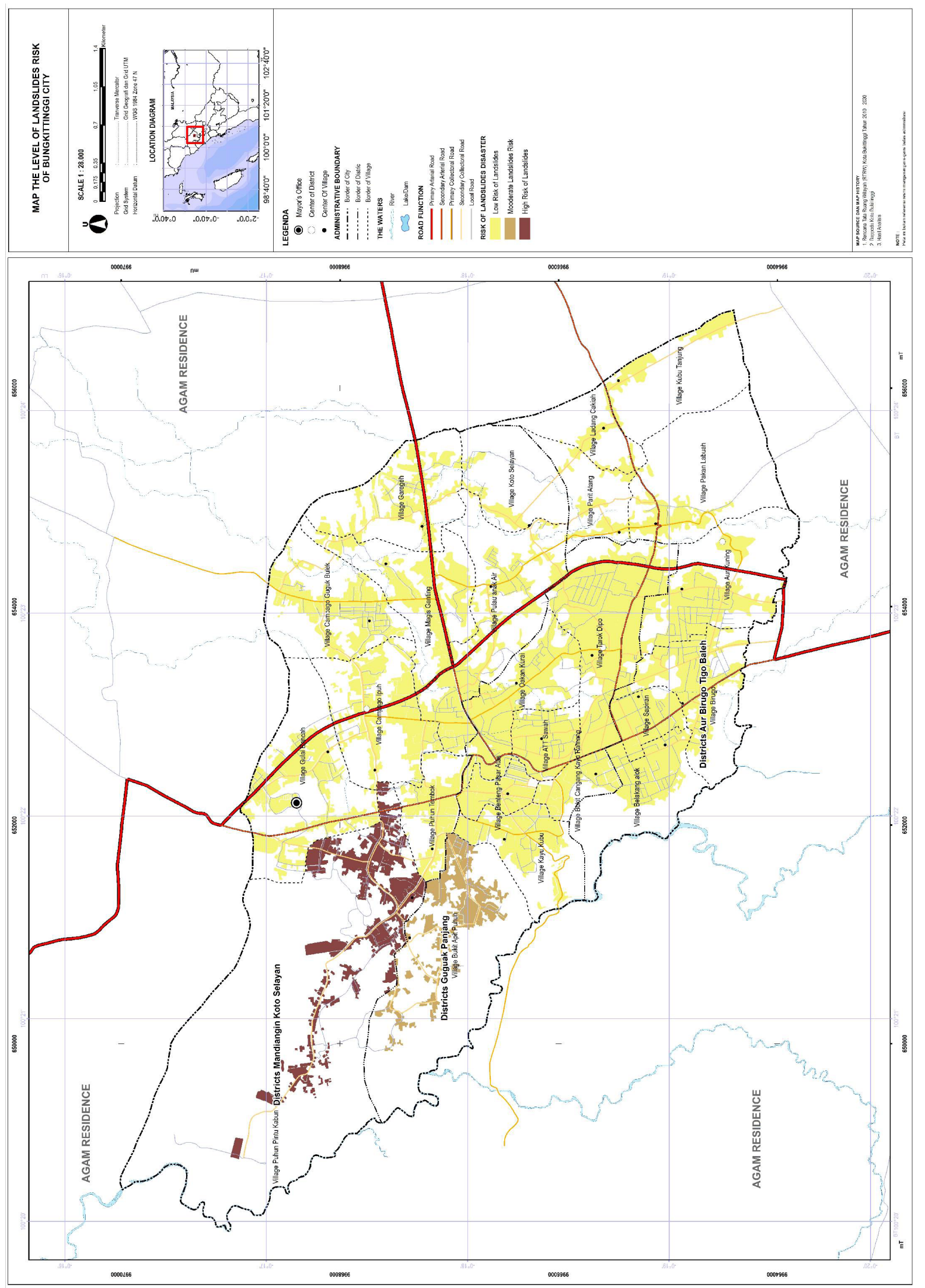

Figure 3. Spatial risk level of landslide 

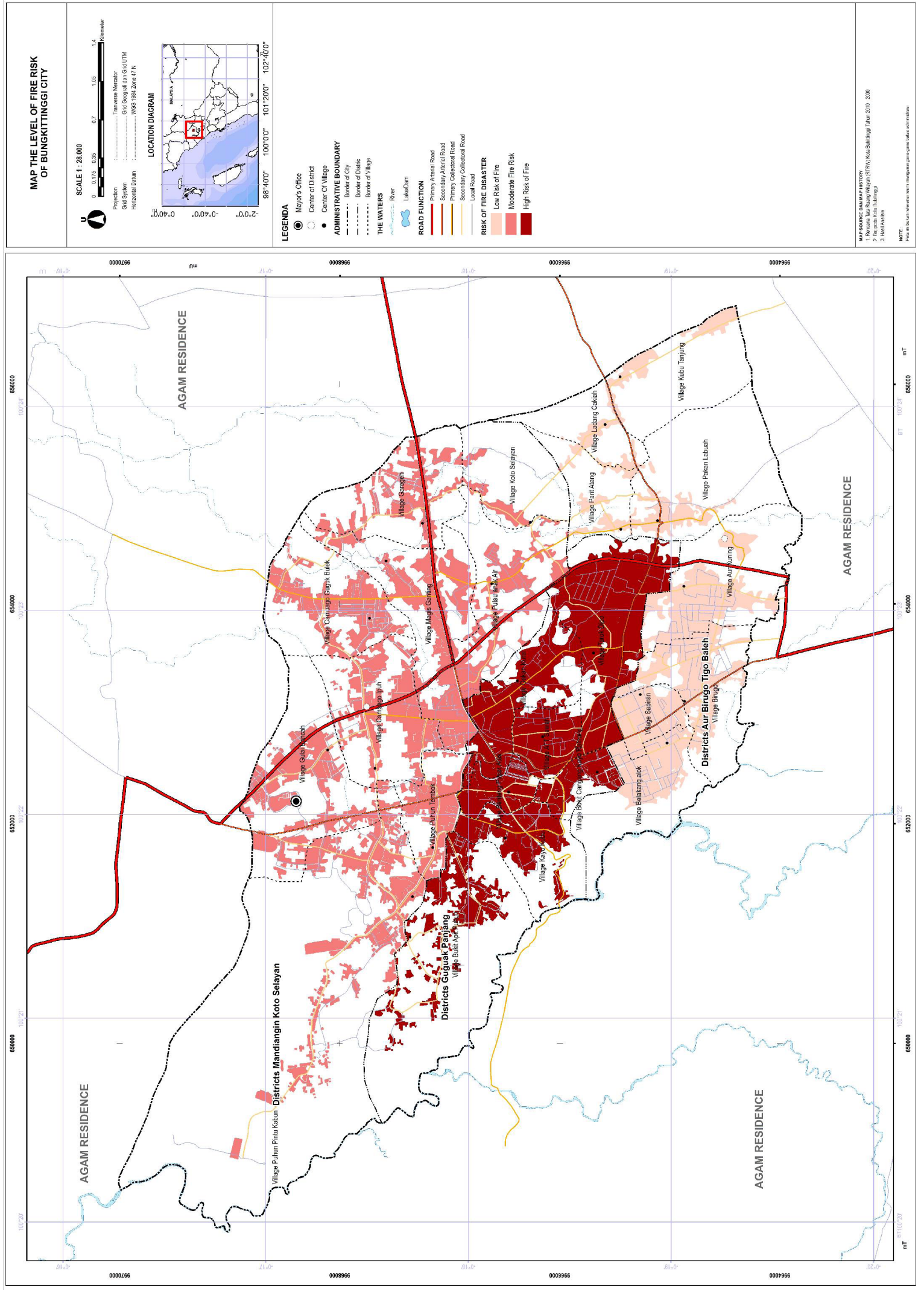

Figure 4. Spatial risk level of fire 

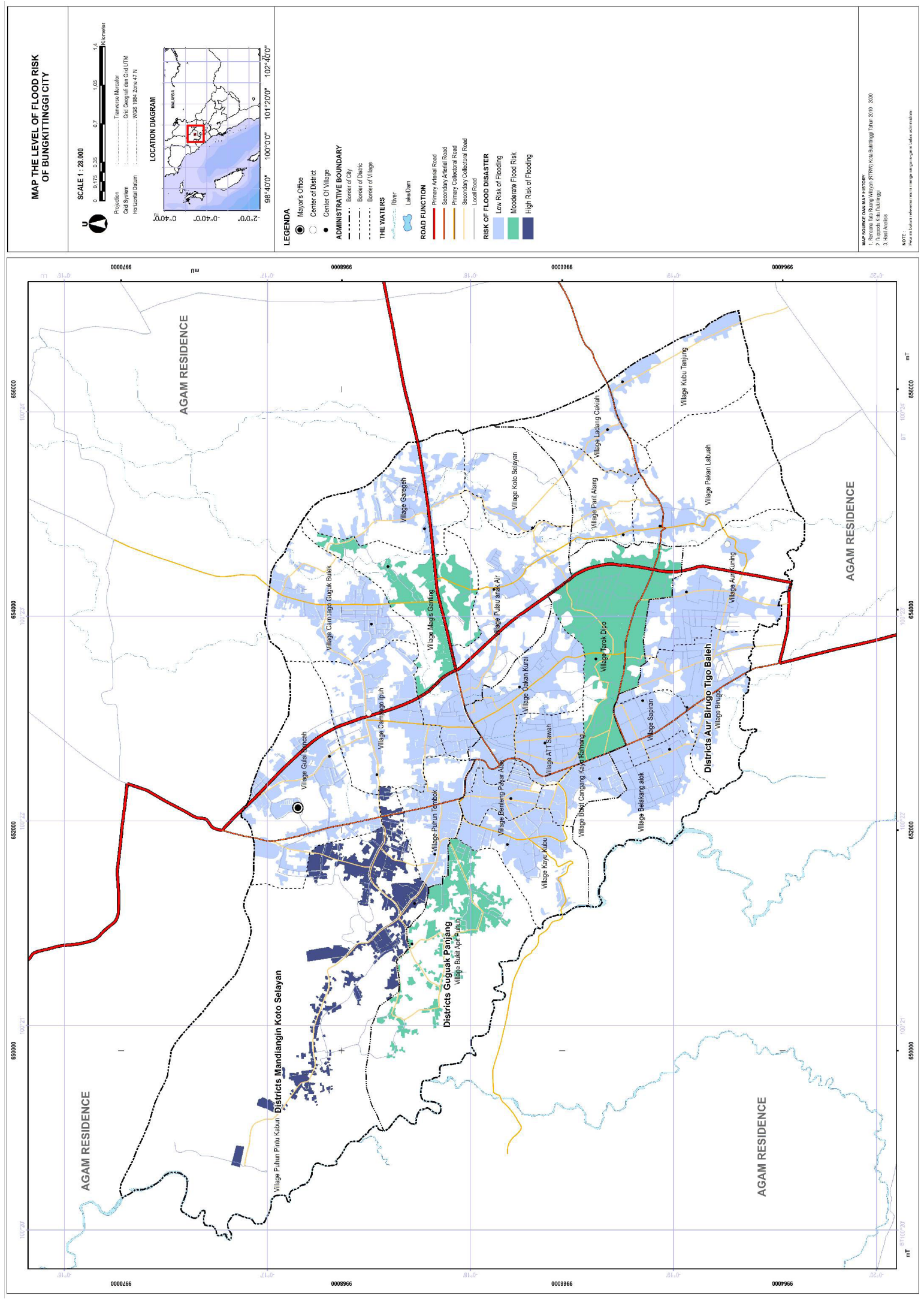

Figure 5. Spatial risk level of floods 


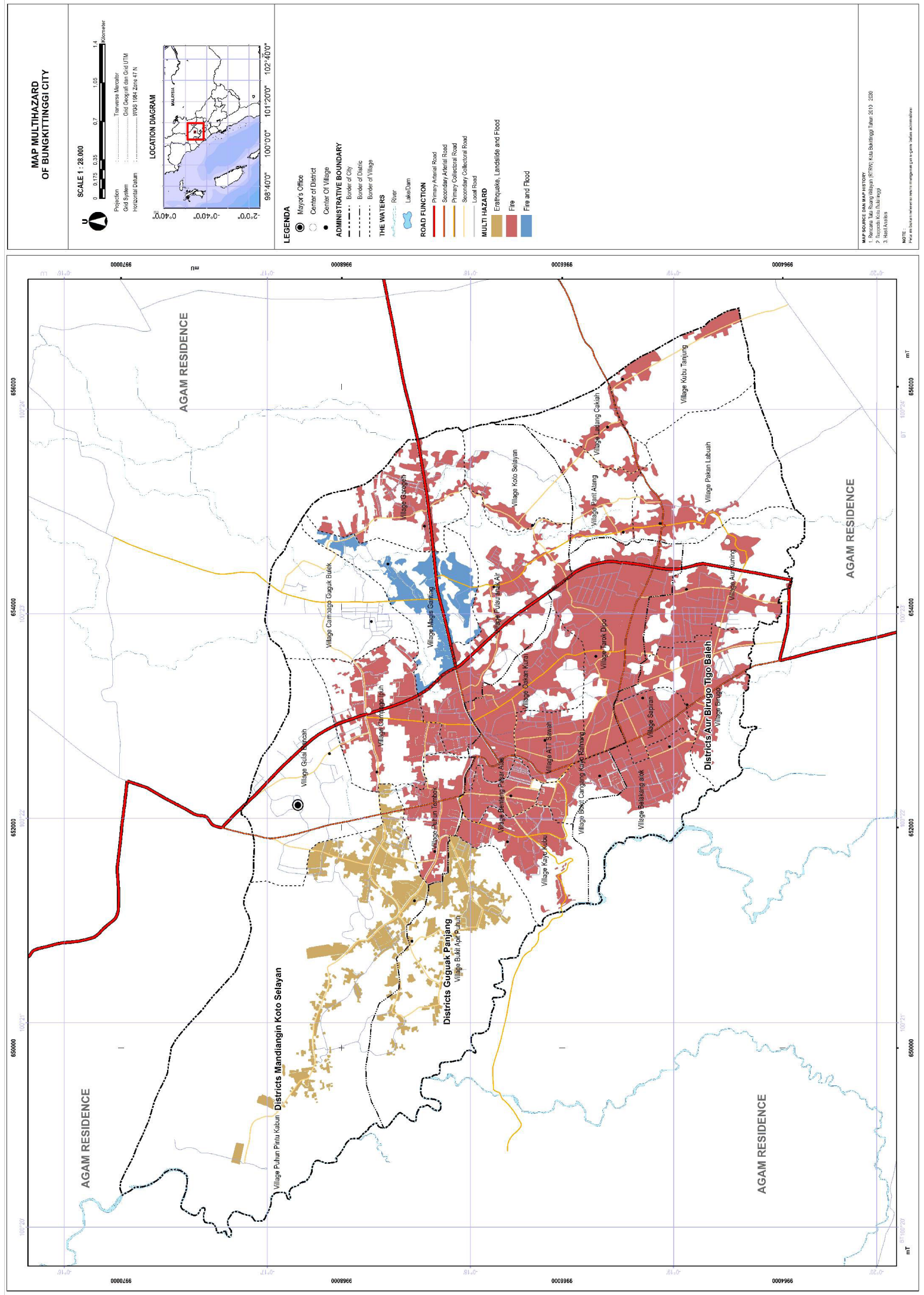

Figure 6. Spatial risk level of multi-hazards 
As a result of multihazard assessment of high, medium and low groupings is essential for the treatment of hazard, vulnerability and capacity or disaster resilience policies and actions. This can all be an input for the implementation of disaster aspects in the spatial planning of Bukittinggi City. Some things that are important in understanding disaster as a basis for decision-making contained in the planning area of Bukittinggi City are:

(1) Total risk reduction is basically the application of prudential principles at each stage of disaster risk management. Disaster risk management is an activity that covers aspects of disaster planning and mitigation, before, during and after a disaster (Robat Mili, Amini Hosseini, \& Izadkhah, 2018). Disaster risk management is a conceptual framework focusing on reducing threats and potential losses and not on disaster management and its consequences. Disaster risk management aims to develop a safe culture and create a disaster-resilient community (Lin, 2018).

(2) The principle of prudence starts from looking at each part of the activity that has the potential to become a threat to the existence of livelihood assets and the human spirit. The threat is slowly or suddenly will potentially become a disaster, thus causing the loss of human soul, property and environment. This incident takes place beyond the adaptability of society to its resources. In this regard it is necessary to understand the potential risks that may arise, namely the magnitude of the loss or the likelihood of loss (life, victim, damage and economic loss) caused by a particular hazard in an area at a certain time. Risks are usually mathematically calculated, the probability of the impact or consequence of a hazard (Thierry et al., 2008). If the potential risks for the execution of activities are much greater than the benefits, then prudence needs to be increased.

The above efforts need to be supported by preparedness efforts, ie making efforts to anticipate disasters (Kim, Pant, \& Yamashita, 2017), through organizing appropriate, effective and alert steps. In the effort of this preparedness is also carried out strengthening early warning system (early warning system), which is an attempt to provide a warning that the disaster is likely to occur soon. This effort is for example by creating a device that will inform the public if there is an unexpected increase of undesirable substance in the river or well around the source of the threat ( $\mathrm{Xu}$ et al., 2018),(Borg et al., 2014). Early warning should be (1) reaching out to the community (accesible), (2) immediate, (3) firmly not confusing (coherent), (4) officially.

(3) Ultimately, if a disaster from a source of threat has to occur, an emergency response (GarciaAristizabal et al., 2015), synergistically also needs relief, which is to provide assistance in relation to the fulfillment of basic needs: food, clothing, shelter, health, sanitation and clean water.

(4) In order for the impact is not prolonged then the process of recovery environmental conditions and affected communities/disaster, by the refunctioning of infrastructure and facilities in the original state. Efforts are made not just improving basic infrastructure and services (roads, electricity, water, market, and health centers) but including ecological functions (Gey, 2014). These efforts, in the short term, generally consist of rehabilitation efforts, namely efforts to help communities improve their houses, public facilities and important social facilities, and revive the wheels of the economy and ecological functions after a disaster occurs. Solving environmental problems so far has only done this physical act, which has not generally touched the rehabilitation of ecological functions. Furthermore, reconstruction is a medium-term and long-term effort for physical, social and economic improvement to restore people's lives in the same condition or better than before.

(5) Each individual, community, or larger social unit develops the capacity of the adjustment system in response (Benton, 2016), especially in the threat of disaster. The response is short-term, socalled adjustment mechanism or more long-term known as adaptation mechanism (Carrasco \& Bilal, 2016). Mechanisms in the face of change in the short term are primarily aimed at accessing basic living needs: security, clothing, food, while long-term aims for the sources of life.

(6) According to the concept of sustainable livelihood, there are five livelihood assets owned by each individual or a higher social unit in its efforts to develop its life (Andriani, 2013; Fu, 2004) namely: [1] funding capital, human capital, among others skill, ability to work, and health; [2] social capital, social property owned by communities such as networks and attachments of trust-based relationships; [3] natural and environmental capital: is a supply of natural resources such as land, water, air quality, protection against erosion.

The occurrence of disasters earthquakes, landslides, floods and fires, whether they are realized or not, will inevitably change the function of community structures, both infrastructure and spatial use patterns in the utilization of Bukittinggi City's spatial plan. The results of this multihazard study are prescriptions or inputs for efforts to restore the function of community structure, land use and infrastructure known as 'rehabilitation'. Rehabilitation is carried out using psychological, sociological and technical approaches including spatial approaches. The 
existence of the Bukittinggi city spatial plan is a spatial-based 'development guidance' where multi-hazard limitation disasters must be faced in the use of spatial plans. The prescription of the substance of the Bukittinggi City spatial planning in multi-hazard mitigation must be able to be implemented in the spatial structure and land use that are the policies, programs and plans.

\section{Conclusion}

Disasters such as earthquakes, landslides, floods in the city of Bukittinggi is still in the area that can be controlled with spatial planning tools, but temporally as community attitudes need for device policy that can change community attitudes about the importance of addressing the dangers of multi-hazard. Fire disaster area is vast because in urban areas should get consideration not only spatially but also through the temporal approach and technical approach to building such a distance, building materials, design, accessibility firefighters can reduce the disastrous fires. Multi-hazard disaster in Bukittinggi spatially can be grouped in clusters, namely: earthquakes, consists of a cluster Bukit Apit Puhun, Cluster Puhun Pintu Kabun; Landslide consist of clusters Bukit Apit Puhun, Cluster Puhun Pintu Kabun; Flooding consists of a cluster of locations Tarok Dipo, Cluster Apit Puhun, Cluster Maggih Genting, Cluster Puhun Pintu Kabun; Fire disaster consists of a cluster of locations Bukik Cangang Kayu Ramang, Cluster Tarok Dipo, Cluster Pakan Kurai, Cluster Aur Tajungkang Tengah Sawah, Cluster Benteng Pasar Atas, Cluster Bukit Apit Puhun, Cluster Maggih Ganting, Cluster Puhun Tembok, Cluster Belakang Balok, Cluster Sapiran, Cluster Birugo, Cluster Aur Kuning. This clustering is very important for spatial-temporal policies to be able to handle and adaptive hazards and mitigation appropriate in the event of a disaster.

\section{Acknowledgement}

Sincerely, thanks to Direktorat Riset dan Pengabdian Masyarakat (The Ministry of Reseach and Higher Education) which makes this research paper possible through the help and funding support (grant). We would also like to thank Lembaga Penelitian (LPMUniversitas Pasundan) as the institution that manages the research activities in our abroad.

\section{References}

Awotona, A. (1997). Reconstruction after disaster: issues and practices. Ashgate Publishing.

Andriani, L. (2013). Social Capital: a Road Map of Theoretical Frameworks and Empirical Limitations (BWPMA 1301 Social). London.

Ayyub, B. M. (2014). Systems Resilience for Multihazard Environments: Definition, Metrics, and Valuation for Decision Making. Risk Analysis, 34(2), 340-355. https:// doi.org/10.1111/risa.12093
Bathrellos, G. D., Skilodimou, H. D., Chousianitis, K., Youssef, A. M., \& Pradhan, B. (2017). Suitability estimation for urban development using multi-hazard assessment map. Science of The Total Environment, 575, 119-134. https:// doi.org/10.1016/j.scitotenv.2016.10.025

Benton, R. A. (2016). Uniters or dividers? Voluntary organizations and social capital acquisition. Social Networks, 44, 209-218. https://doi.org/10.1016/j. socnet.2015.09.002

Berke, P. R., \& Campanella, T. J. (2006). Planning for postdisaster resiliency. The Annals of the American Academy of Political and Social Science, 604(1), 192-207.

Borg, R. P., Indirli, M., Romagnoli, F., Rochas, C., \& Kuzñecova, T. (2014). The ANDROID Case Study; Venice and its Territory: Vulnerability and Resilience in Multi-hazard Scenarios. Procedia Economics and Finance, 18(September), 825-836. https://doi.org/10.1016/S22125671(14)01008-9

Carrasco, M. A., \& Bilal, U. (2016). A sign of the times: To have or to be? Social capital or social cohesion? Social Science \& Medicine, 159, 127-131. https://doi.org/10.1016/j. socscimed.2016.05.012

Campanella, Thomas J. and Godschalk, David R (2012). Resilience. the Oxford Handbook of Urban Planning. Weber, Rachel and Crane, Randall. Oxfor: Oxfor University Press.

Carter, N. W. (2008). Disaster management: A disaster manager's handbook. Asian Development Bank. Asian Development Bank. Retrieved from bases.bireme.br VN - readcube.com

Collins, M. L., \& Kapucu, N. (2008). Early warning systems and disaster preparedness and response in local government. Disaster Prevention and Management: An International Journal, 17(5), 587-600. https://doi. org/10.1108/09653560810918621

$\mathrm{Fu}$, Q. (2004). Trust, Social Capital, and Organizational Effectiveness. Blacksburg, VA.

Fuchs, S., Keiler, M., \& Zischg, A. (2015). A spatiotemporal multi-hazard exposure assessment based on property data. Natural Hazards and Earth System Science, 15(9), 2127-2142. https://doi.org/10.5194/nhess-15-2127-2015

Garcia-Aristizabal, A., Bucchignani, E., Palazzi, E., D’Onofrio, D., Gasparini, P., \& Marzocchi, W. (2015). Analysis of non-stationary climate-related extreme events considering climate change scenarios: an application for multi-hazard assessment in the Dar es Salaam region, Tanzania. Natural Hazards, 75(1), 289-320. https://doi. org/10.1007/s11069-014-1324-z

Gey, A. (2014). Urban-nature relationships in urban planning foresight in Europe: contributions from the Concours Internationale du Grand Paris. Town Planning Review, 85(5), 589-616. https://doi.org/10.3828/tpr.2014.36

Ghermandi, L., Beletzky, N. A., de Torres Curth, M. I., \& Oddi, F. J. (2016). From leaves to landscape: A multiscale approach to assess fire hazard in wildland-urban interface areas. Journal of Environmental Management, 183, 925937. https://doi.org/10.1016/j.jenvman.2016.09.051

Hemingway, R., \& Gunawan, O. (2018). The Natural Hazards Partnership: A public-sector collaboration across the UK for natural hazard disaster risk reduction. International Journal of Disaster Risk Reduction, 27, 499-511. https:// doi.org/10.1016/j.ijdrr.2017.11.014 
Jaimes, M. A., Reinoso, E., \& Esteva, L. (2015). Risk Analysis for Structures Exposed to Several Multi-Hazard Sources. Journal of Earthquake Engineering, 19(2), 297-312. https://doi.org/10.1080/13632469.2014.962673

Jayasuriya, S., \& McCawley, P. (2010). The Asian Tsunami: Aid and Reconstruction after a Disaster. (E. Elgar, Ed.) (In collabo). Massachusetts 01060: Asian Development Bank Institute.

Kappes, M. S. (2011). Multi-Hazard Risk Analyses : a Concept and its Implementation. Universitat Wien.

Kappes, M. S., Keiler, M., von Elverfeldt, K., \& Glade, T. (2012). Challenges of analyzing multi-hazard risk: a review. Natural Hazards, 64(2), 1925-1958. https://doi. org/10.1007/s11069-012-0294-2

Kim, K., Pant, P., \& Yamashita, E. (2017). Integrating travel demand modeling and flood hazard risk analysis for evacuation and sheltering. International Journal of Disaster Risk Reduction. https://doi.org/10.1016/j. ijdrr.2017.10.025

Komendantova, N., Mrzyglocki, R., Mignan, A., Khazai, B., Wenzel, F., Patt, A., \& Fleming, K. (2014). Multihazard and multi-risk decision-support tools as a part of participatory risk governance: Feedback from civil protection stakeholders. International Journal of Disaster Risk Reduction, 8, 50-67. https://doi.org/10.1016/j. ijdrr.2013.12.006

Lin, L. (2018). Integrating a national risk assessment into a disaster risk management system: Process and practice. International Journal of Disaster Risk Reduction, 27, 625631. https://doi.org/10.1016/j.ijdrr.2017.08.004

Lin Moe, T., \& Pathranarakul, P. (2006). An integrated approach to natural disaster management. Disaster Prevention and Management: An International Journal, 15(3), 396-413. https://doi.org/10.1108/09653560610669882

Perry, R. W., \& Lindell, M. K. (2008). Volcanic risk perception and adjustment in a multi-hazard environment. Journal of Volcanology and Geothermal Research, 172(3-4), 170178. https://doi.org/10.1016/j.jvolgeores.2007.12.006

Purwandari, T., Hadi, M. P., \& Kingma, N. C. (2011). a Gis Modelling Approach for Flood Hazard Assessment in Part of Surakarta City, Indonesia. Indonesian Journal of Geography, 43(1), 63-80. Retrieved from http://oaister. worldcat.org/title/gis-modelling-approach-for-floodhazard-assessment-in-part-of-surakarta-city-indonesia/ oclc/759395522\&referer=brief_results

Robat Mili, R., Amini Hosseini, K., \& Izadkhah, Y. O. (2018). Developing a holistic model for earthquake risk assessment and disaster management interventions in urban fabrics. International Journal of Disaster Risk Reduction, 27, 355-365. https://doi.org/10.1016/j. ijdrr.2017.10.022
Röthlisberger, V., Zischg, A. P., \& Keiler, M. (2017). Identifying spatial clusters of flood exposure to support decision making in risk management. Science of The Total Environment, 598, 593-603. https://doi.org/10.1016/j. scitotenv.2017.03.216

Sakijege, T. (2013). Managing Flood Risks: Lessons From Keko Machungwa Informal Settlement in Dar Es Salaam, Tanzania. IJG Indonesian Journal of Geography, 45(451), $1-14$.

Sanderson, D. (1997). Building Bridges to Reduce Risk. Dalam Reconstruction After Disaster: Issues and Practices. Awotona, Adenrale (ed)(1997).

Thierry, P., Stieltjes, L., Kouokam, E., Nguéya, P., \& Salley, P. M. (2008). Multi-hazard risk mapping and assessment on an active volcano: the GRINP project at Mount Cameroon. Natural Hazards, 45(3), 429-456. https://doi. org/10.1007/s11069-007-9177-3

van Verseveld, H. C. W., van Dongeren, A. R., Plant, N. G., Jäger, W. S., \& den Heijer, C. (2015). Modelling multihazard hurricane damages on an urbanized coast with a Bayesian Network approach. Coastal Engineering, 103, 1-14. https://doi.org/10.1016/j.coastaleng.2015.05.006

van Westen, C. J., van Asch, T. W. J., \& Soeters, R. (2006). Landslide hazard and risk zonation-why is it still so difficult? Bulletin of Engineering Geology and the Environment, 65(2), 167-184. https://doi.org/10.1007/ s10064-005-0023-0

Wong, K. H., \&Xie, D. (2014). Fire Safety Management Strategy of Complex Developments. Procedia Engineering, 71, 410-420. https://doi.org/10.1016/j.proeng.2014.04.059

Xu, Z., Lu, X., Cheng, Q., Guan, H., Deng, L., \& Zhang, Z. (2018). A smart phone-based system for post-earthquake investigations of building damage. International Journal of Disaster Risk Reduction, 27(October), 214-222. https:// doi.org/10.1016/j.ijdrr.2017.10.008

, (2011) Bukittinggi City Regional Regulation No. 6 of 2011 on Spatial Planning (RTRW) of Bukittinggi City. (2014), Performance Report, Regional Disaster Management Agency, Bukittinggi City , Act Number 24 Year 2007 on disaster management. 